\title{
NAD-Dependent Protein Deacetylase Sirtuin-7
}

National Cancer Institute

\section{Source}

National Cancer Institute. NAD-Dependent Protein Deacetylase Sirtuin-7. NCI Thesaurus. Code C102772.

NAD-dependent protein deacetylase sirtuin-7 (400 aa, $45 \mathrm{kDa}$ ) is encoded by the human SIRT 7 gene. This protein plays a role in protein deacetylation. 